\title{
Max Nordau, amigo de las letras hispanoamericanas
}

Por los años de 1895 a 1900 vivían en París Rubén Darío y Enrique Gómez Carrillo. Más tarde llegaron Amado Nervo, Rufino Blanco-Fombona, Francisco Contreras y otros muchos a dar mayor lustre al pequeño grupo literario americano establecido allí. Todos estos autores se encaminaban a París con la intención de mejorar de ambiente. La leyenda de París había sido fomentada por los primeros que se establecieron allí y con la ayuda de importantes diarios como La Nación de Buenos Aires.

Por entonces fué muy conocida la obra de Max Nordau, escritor también radicado en París. Nordau nació en Budapest en 1849 . En I880 se estableció en París como médico. Se interesaba en la historia, la literatura y la filosofía y en I 883 publicó la mezcla de estos intereses en Conventionelle Lügen der Kulturmenschheit (Mentiras convencionales de la civilización). Otras de sus obras son Parandoxe y Die Krankheit des Jahrhunderts (La enfermedad del siglo). Su obra principal Entartung apareció en I893. Fué conocida por muchos escritores hispanoamericanos en la traducción francesa de Dégénérescence; Justo Sierra cita el título francés en lugar del español Degeneración en el prólogo que escribió a Peregrinaciones de Darío. Entartung fué muy comentado y criticado. En él trata Nordau de demostrar que muchos de los artistas y autores de fi- 
nes del siglo XIX son degenerados y que poseen las características de criminales. Dice que sus malsanos deseos se satisfacen en la creación artística, la cual para Nordau carece de valor. La importancia de Nordau fué pasajera. Fué conocido y respetado por numerosos autores, pero su dogmatismo y su pose moralizadora no le permitieron crearse un puesto duradero. Entre los hispanoamericanos fué muy bien acogido. La importancia que los literatos americanos le dieron la merecía como pago por el interés que él mostró en ellos.

En los momentos en que Nordau se conquistaba renombre en Europa y en América, empezaban en serio las labores literarias de Darío, Gómez Carrillo y otros radicados en París. Darío y Gómez Carrillo escribían para La Nación y Nordau se dedicaba también a tareas periodísticas. Ya en $\mathrm{I} 893$ Nordau le es conocido a Darío y éste le dedica un capítulo en Los raros. Cinco años más tarde Gómez Carrillo no cree que Nordau sea un raro. ( I) Gómez Carrillo fué quien mejor conoció a Nordau y al examinar sus obras hallamos los primeros indicios de las influencias que pudo haber ejercido el doctor judio.

La influencia que ejerció Nordau sobre los autores hispanoamericanos en París puede dividirse en dos partes. Primero, les trajo a la atención los nuevos procedimientos psico-patológicos y les hizo ver su importancia en la literatura. Segundo, ayudó y dió ánimo a los autores americanos que se encontraban en un ambiente un tanto indiferente.

Gómez Carrillo fué de los primeros en seguir a Nordau; no sólo emplea ciertos procedimientos en sus novelas que aprendió de Nordau, sino que cree indispensable adoptar las nuevas ideas a la crítica literaria:

"Empero, no hay más que leer en los libros de Max Nordau y de Ebing ( $\mathrm{sic}$ ) los catálogos de novelas en las cuales hay un fondo de sadismo, de masoquismo o de fetichismo, para comprendẹ que el estudio de esos relatos secos y técnicos son de

(I).-Gómez Carrillo, E., Sentsaciones de Paris y de Madrid, Paris, Igoo, pag. I22. 
una utilidad casi indispensable a los que desean darse cuenta del desequilibrio erótico y sensitivo de la literatura actual". (I)

"Los jóvenes literatos - me decía el autor de Degeneraciónhan tomado casi todas sus imaginaciones macabras en los casos patológicos descritos por los grandes psiquiatristas (sic) contemporáneos. Si quiere usted conocer la fuente de todo lo extraordinario de la novela moderna, lea usted la Psicopatía se*ual". (2)

Rufino Blanco-Fombona también reconoce el valor de las nuevas teorías de Nordau y hace el siguiente comentario en su libro Letras y letrados de Hispano-América:

"Por eso la crítica - la crítica de antaño- es muy escabrosa. Un crítico no tiene derecho ni poder para decretar la excelencia o la mediocridad de una obra. Cuando no sea el estudio patológico de un autor, a la manera que suele practicarlo el doctor Max Nordau, o análisis desinteresado, profundo, psicológico, del hombre en relación con la obra y de la obra en relación con el hombre..." (3)

Para otros autores americanos, como para estos que citamos, las nuevas ideas fueron una revelación. Krafft-Ebing, Sacher-Masoch y después Freud principiaron a ser conocidos de la intelectualidad americana gracias a un pequeño grupo de literatos que en París se familiarizaron con Nordau o con su obra. Es difícil determinar cómo se establecieron relaciones intimas entre Nordau y el grupo hispanoamericano. (Gómez Carrillo más tarde ataca a Nordau con vigor). Nordau se había hecho de las más firmes enemistades con su Entartung y tenía un carácter huraño y antipático. Sus ideas, a la vez, impulsadas por un sentido archiapostólico eran todo lo contrario

(1).-Gómez Carrillo, E., Almas y cerebros, historias sentimentales, intimidades parisienses, París, I898. pág. 326.

(2).-Gómez Carrillo, E., Ibid. pág. 326 seq.

(3).-Blanco-Fombona, R., Letras y letrados de Hispano-América, París, Ipo8, pág. 302 . 
de las que se podian hallar en los escritores hispanoamericanos fin de siècle en París. No obstante, durante unos años Nordau fué buten amigo de casi todos los escritores hispanoamericanos en París. Su nombre aparece con frecuencia en los libros publicados en París por los años de igoo. A Blanco-Fombona le llama en una carta cher et très éminent confrère. Gómez Carrillo llama maestro a Nordau en varios artículos E! interés que manifestaba Gómez Carrillo atrajo la atención de Clarín, quien le aconseja que abandone a ese falso apóstul:

"Max Nordau no es un sabio, no es un filósofo, no es un artista.. Max Nordan cultiva la especialidad de la brocha gorda y da escobazos, alli donde harían falta los más sutiles pinceles". (I)

Justo Sierra dice haber conocido a Nordau.

Nordau mostró grande interés en las letras hispanoamericanas y en el porvenir cultural de la América Hispana en general. Conocía bien a Darío y con él debe haber conversado de los problemas de la joven literatura, pues éste nos dice:

"La idtea de Max Nordau no anda nuy lejos de la verdad, al ver en lo porvenir una rica primavera para el pensamiento americano". (2)

Alabó las producciones literarias de los autores americanos en París, diciendo de una colección de sonetos de Francisco Contreras:

"Es realmente un toisón de oro suntuoso, fabuloso, digno objeto de la heroica aventura de Jasón, fin feérico de la navegación del Argos". (3)

(1).-Citado por Cáceres, Aurora, en Mi vida con Enrique Gómes Carrillo, Madrid y Buenos Aires, 1929 pág. 29.

(2).-Gómez Carrillo, E., Almas y cerebros... Pról. X.

(3).-Darío, Rubén, La caravana pasa, París igo2. pág. I6o. 
De uno de los libros de Gómez Carrillo dice Nordau con exagerado estusiasmo:

"Ha hecho usted una bella obra. Hay un encanto helénico en la prosa de sus poemas..." (I)

Blanco-Fombona aceptó sus teorías y las utilizó en algunas de sus críticas literarias. En I908 como muestra de cariño le dedicó su libro Letras y letrados de Hispano-América, o mejor dicho, lo dedicó a Nordau y a Vargas Vila.

Como se dijo arriba, la influencia de Nordau no fıé grande. Por razones de que hemos hablado se le aceptó y se le siguió más de lo debido entre los hispanoamericanos en París. Algunos cultivaron su amistad para hacer uso de su nombre, otros verdaderamente vieron en Nordau un nuevo líder intelectual. Sus teorías han pasado al olvido, pero en la literatura hispanoamericana aún hay htellas de la ayuda que Nordau prestó y huellas de los elementos psicopatológicos que él popularizó. Nordaı sirvió, como pocos escritores europeos, de estímulo; reconoció el valor de la literatura hispanoamericana y tuvo fe en ella en momentos críticos de su desarrollo.

$$
\begin{aligned}
& \text { José Luis LunA, } \\
& \text { Universidad de Califomina, Berkeley }
\end{aligned}
$$

\footnotetext{
XI.

(1).-Contreras, Francisco, La piedad sentimental, París, 1912? Pról.
} 
